\title{
Psychological Intervention in Psychotic Crisis: a person-centered approach
}

\author{
Intervenção Psicológica em Crise Psicótica: \\ uma abordagem centrada na pessoa
}

Guilherme Wykrota TOSTES 1 (iD) 0000-0001-6873-9889

vera Engler CURY1 (iD) 0000-0003-2721-3367

\begin{abstract}
This article describes, theoretically analyzes, and exemplifies, through a fictitious vignette, a psychological intervention of a clinical nature, developed by psychologists in a tertiary mental health care hospital, as an alternative to conventional physical restraint in situations of acute psychotic crises. The theoretical framework adopted is Person-Centered Approach, developed by the North American psychologist Carl Rogers. The psychological intervention reveals the importance of an interpersonal relationship in the care of patients who are going through a psychotic crisis. The psychologist's therapeutic posture includes the three attitudes advocated by Carl Rogers as necessary and sufficient to facilitate the process of resuming personal autonomy (congruence or authenticity, unconditional positive regard, and empathic understanding), in addition to confidence in the patient's own actualizing tendency. The therapeutic strategy presented is a possible resource to be used to stabilize the person in crisis. These attitudes were initially proposed by Rogers and his team to develop and maintain a psychotherapeutic intervention process, but they also proved to be effective in the experience of Brazilian psychologists in relation to patients with severe mental disorders in acute crises.
\end{abstract}

Keywords: Client centered therapy; Crisis intervention; Empathy; Humanistic psychology; Psychological intervention; Psychotic episode.

\section{Resumo}

Este artigo descreve, analisa teoricamente e exemplifica por meio de uma vinheta fictícia uma intervenção psicológica de natureza clínica, desenvolvida por psicólogos num serviço de atenção terciária em saúde mental, como alternativa à contenção física convencional em situações de crises psicóticas agudas. O referencial teórico adotado é a Abordagem

$\nabla \nabla \nabla v$

1 Pontifícia Universidade Católica de Campinas (PUC-Campinas), Centro de Ciências da Vida, Programa de Pós-Graduação em Psicologia. Av. John Boyd Dunlop, s/n., Prédio Administrativo CCV, Jd. Ipaussurama, 13060-904, Campinas, SP, Brasil. Correspondence to: V.E. CURY. E-mail: <vency2985@gmail.com>.

$\boldsymbol{\nabla} \nabla \mathbf{v}$

How to cite this article

Tostes, G. W. \& Cury, V. E. (2021). Psychological Intervention in Psychotic Crisis: a person-centered approach. Estudos de Psicologia (Campinas), 38, e200106. https://doi.org/10.1590/1982-0275202138e200106 
Centrada na Pessoa, desenvolvida pelo psicólogo norte americano Carl Rogers. A intervenção psicológica disponibilizada desvela a importância da relação interpessoal no cuidado a pacientes que passam por crise psicótica. A postura terapêutica do psicólogo inclui as três atitudes preconizadas por Carl Rogers como necessárias e suficientes para desencadear um processo de retomada da autonomia pessoal (congruência ou autenticidade, consideração positiva incondicional e compreensão empática), além da confiança na tendência atualizante do paciente. A estratégia terapêutica apresentada consiste num recurso possível a ser utilizado para a estabilização da pessoa em crise. Estas atitudes foram propostas, inicialmente, por Rogers e equipe para o desencadeamento e manutenção de um processo de intervenção psicoterápica, mas mostraram-se eficazes, também, na experiência de psicólogos brasileiros em relação a pacientes com transtornos mentais graves em situação de crise aguda.

Palavras-chave: Terapia centrada no cliente; Intervenção na crise; Empatia; Psicologia humanista; Intervenção psicológica; Episódio psicótico.

The present article aims to present a theoretical analysis about psychological intervention in the case of patients in acute psychotic crisis based on the assumptions of the Person-Centered Approach, developed by the North American psychologist Carl Rogers in the context of Client-Centered Therapy. This type of intervention was carried out by one of the authors with fellow psychologists in a tertiary mental health care hospital, as an alternative to conventional physical restraint in situations of an acute psychotic crisis. Aiming to describe and exemplify the clinical occurrence of this type of intervention, under a phenomenological perspective, a fictitious vignette based on multiple experiences of one of the authors will be presented. This study aims to contribute to support the development of psychological intervention practices that consider the subjective experience of suffering experienced by people in situations of psychotic crisis. It is a brief psychological intervention, in an emergency situation, which aims to offer support through an intersubjective relationship to the reengagement of the patient, a contact with reality, in order to promote their stabilization.

The psychological intervention that we intend to describe incorporates certain attitudes by the team of psychologists with the intention of contributing to the stabilization of patients who experienced mental suffering in a situation of acute psychotic crisis; it is a clinical strategy that privileges the team's own intersubjective relationship with the patient.

It is noteworthy that a standard operational protocol was developed in this hospital institution, given the therapeutic efficacy provided by the active presence of professional psychologists in the manifestations of mental suffering of patients in crisis situations; the objective of this document was to ensure the presence of a member of the psychology team to carry out the first interventions in these cases. The scope of this institutional protocol was the humanization of professional practices aimed at coping with crisis situations in patients in hospital custody. In preparation of this protocol, the experience of the psychology team played a central role, as the presence of a psychologist became mandatory in any case of acute crisis and prior to any attempt at physical or chemical restraints by the other teams, medical or nursing.

In order to illustrate the context and describe the intervention process more clearly, a "fictional narrative" was created. This narrative was structured from fragments of life stories that were "shuffled", creating a "collage" based on real facts, but which is read as fiction so that "no character can be identified in real life, since none of them reflect a single person" (Reigota, 1999, p. 74, in our own translation)2.

It was a cold June morning. The infirmary remained silent. As always, this silence would soon give way to the usual noises, the coming and going of people, conversations, and handling cardboard and other materials in occupational therapy groups. That day, however, something broke the routine. The space was invaded by the sound of glass being broken and brass being kicked. These noises were coming from the first-floor

2 In the original: "nenhum personagem pode ser encontrado na vida real conforme descrito, pois nenhum é reflexo de uma única pessoa" (Reigota, 1999, p. 74). 
infirmary. Heads snapped up, and some of the patients who were closest rushed toward the noise. We found a daunting scene: Gustavo was breaking and kicking everything that was in his reach. There was a lot of broken glass on the floor, in addition to the garbage that had been scattered all over the place, and chairs that were thrown, ending up in the corners of the room. Some members of the nursing staff tried to make him stop, but he kept going, determined and impulsive. The nursing technicians screamed for help while one of them communicated by radio to the other professionals that it was a "red code in Inpatient Unit 2".

This situation is not unusual for professionals working in tertiary mental health care services in the case of patients with acute mental suffering. Still, these symptoms demand a quick response from the teams in order to contain the patient, before they hurt other people or themselves. The scene could proceed as follows, if we were to illustrate the traditional way of restraining still very present in today's hospital contexts:

As each member of the therapeutic team had access to a radio for internal communication with the others, upon hearing the call from the nursing attendant, one of the two nursing technicians, present in each of the units, immediately rushed to the said location. Quickly, at the door of "Unit 2", a team of 6 men dressed in white was formed and, together, they entered the unit where Gustavo was. Feeling more supported by his colleagues, Carlos, the attendant, unlocked the nursing station to get some sheets and the appropriate restraining bands to contain patient. Before that, the nursing technicians tried a quick verbal approach with Gustavo, telling him they wanted to help him and trying a negotiation to calm him down. To no avail, they decided it would be better to physically contain him. They also gave him chemical restraining drugs, after an assessment by the psychiatrist on duty. Due to the fact that Gustavo was very tense, with his muscles contracted, the medication took time to take effect. After an hour, still under restraint, Gustavo finally fell asleep.

The conventional procedure in crisis situations in institutions of this nature is the use of physical and/or chemical restraint. Eugenio Borgna, an Italian psychiatrist, criticizes the traditional clinical context in which mental health professionals silence patients as a therapeutic resource. Borgna (2019) states that psychiatry is going through a period of significant ambivalence and attributes that point to a deep reductionism in the understanding of the human being and denounces this reductionism in his studies on the matter. This points to a unilaterality in the analysis of the human phenomenon through biological reductionism, which comprises psychic acts exclusively from the direct expression of a neurophysiological or neurochemical organic alteration (Borgna, 2003, 2019). He points out that (Borgna, 2003, p. 30, in our own translation) $)^{3}$ :

The cognitive and conceptual paths, with which biological psychiatrists are confronted with psychotic experiences, depressions, and anxiety and obsessive syndromes, are marked by the identification of psychic and physical phenomena, by the annulment of the psychic dimension of human life, by the reduction of subjectivity to objective biological manifestations, and by human individuality to a reality that has nothing to do with the questions of nature.

According to Borgna $(2003,2019)$, the medicalization of human experiences, proposed by biological logic, has eclipsed the constitution of a dialogic human encounter, which, according to him, is the fundamental resource for an effective treatment when it comes to psychic suffering.

\footnotetext{
$\mathbf{v} \mathbf{v} \boldsymbol{v}$
}

$\mathbf{3}$ In the original: "I modi conoscitivi e concettuali, con cui le psichiatrie biologiche si confrontano con le esperienze psicotiche e con le depressioni, con le sindromi ansiose e con quelle ossessive, sono contrassegnati (sono ipotecati) dalla identificazione dei fenomeni psichici nei fenomeni fisici, dalla cancellazione dela dimensione psichica dela vita umana, dalla riduzione della soggettività a prestazione biologica oggettivabile e della individualità umana a uma realtà che non ha nulla di particolare nei confronti della natura" (Borgna, 2003, p. 30). 


\section{Psychological intervention in psychotic crisis: historical data and current scientific production}

The researcher and psychiatrist Caplan (1980), an exponent in the development process of North American psychiatry focused on prevention, found that his patients showed long-term psychological deterioration, after the end of a psychotic crisis. Based on these conclusions, he decided to develop preventive strategies, seeking to prevent patients from triggering such crises. Caplan (1980) understood that the meaning of the crisis lay in the development of a temporal condensation, a moment in which important changes in the person's psychic structure could occur in a relatively short period. Such imbalance would result from a stimulus that would signal imminent danger to the satisfaction of fundamental needs or would trigger a particular need. Added to this, the alternatives available to the person in crisis to resolve the internal conflict are not sufficient from a subjective point of view. Caplan (1980) described four phases present in these crises: in Phase 1, the author argues that the increase in tension generated by the psychological impact of the stimulus mobilizes habitual homeostatic responses to solve problems; Phase 2 is characterized by the lack of success and continuation of the stimulus that determine the increase in tension and the state of alteration and ineffectiveness; in Phase 3, the tension continues to increase and goes beyond this third phase, starting to act as a powerful subjective stimulus for the mobilization of internal and external resources; it is a time when the individual resorts to their energy reserves and their defensive mechanisms, responding to emergency situations, to solve the problem, even using new techniques to face what is considered as a threat; at this point, as a result of this mobilization of efforts, the problem may decrease in intensity and resolve itself; in Phase 4, if the problem continues and cannot be resolved by satisfying the need or is avoided through resignation in the face of dissatisfaction or perceptual distortion, the tension rises to a breaking point, causing a major disorganization in the individual's functioning, with serious results.

Slaikeu (1988) in an extensive manual on crisis interventions refers to the psychotic crisis as a temporal state of disorder and disorganization during which the person is unable to handle specific situations using methods which they are accustomed with for troubleshooting. This author identifies two fundamental types of human crises: (a) one related to the stages in the life development process, which has the following characteristics: feelings of despair, negativity, danger, and disorganization; (b) one related to circumstantial life events, which has the following characteristics: sudden appearance, unpredictability, urgency, potential impact on entire communities, danger, and opportunity (Slaikeu, 1988). The author defines "crisis intervention" as a form of intervention with a focal character that proposes to offer assistance to the person in distress so that they can overcome the risk of loss of mental health and seek to solve harmful problems, to take the person out of harm's way, benefitting their personal development (Slaikeu, 1988).

Rojo and Peral (2009) define "psychotic crisis" as a moment when the person suffers a serious deterioration of their mental functioning and somehow loses contact with reality, and with the capacity for introspection in facing the demands of the everyday life; it can be configured in the form of confusional states, as well as bizarre and agitated behavior with the predominance of delusions, hallucinations, and disorganized language and behavior, as well as significant changes in mood. There is also the presence of changes in recent memory or changes in the experience of time, accompanied by changes in self-awareness. These authors draw attention to other characteristics present in these situations: (a) intimacy, proximity, or physical contact can be considered threatening; (b) the person in a psychotic crisis is afraid of everything and sees everyone as a stranger, confusing these internal experiences with reality; (c) the ability to take care of oneself, eat, take medicines, or care for other people may be affected. Regarding interventions in the psychotic crises, Rojo and Peral (2009) also highlight: (a) assessing the situation: to what extent is the individual a risk for themselves and they cannot take care of themselves? To what extent is the individual a risk to others? What is the most appropriate context to help them? What support does the person have? (b) communication: the objective 
of the team engaged in this type of emergency is to communicate with the person and help them manage the crisis by themselves, with the help of professionals, facilitating a resolution.

From the point of view of how the person verbally communicates what is happening to them, these authors refer to the fact that they are living an experience they cannot process normally, since psychosis distorts the personal narrative to such an extent that the lived experience cannot be explained in the usual way because it would not be understandable. One of the objectives of the intervention proposed by Rojo and Peral is to take the person in crisis to a clinical assessment to discover the most suitable pharmacological treatment to reduce their psychotic symptoms, with the aim of reducing suffering and restoring their balance.

Prouty (2003), a North American humanistic psychologist, developed an original proposal of intervention to be carried out with people with severe, chronic suffering based on the contributions of the Carl Rogers's Person-Centered Approach and the Experiential Psychology developed by Eugene Gendlin. He called this intervention "pre-therapy". It seeks to shed light on the dimensions and difficulties experienced by psychologists in the process of establishing interpersonal contact with people who are more psychologically regressed. Prouty defined pre-therapy as a theory about psychological contact that aims at "the development or establishment of the necessary functions for the therapeutic relationship and experience" (Prouty, 2003, p. 45, in our own translation) ${ }^{4}$. For him, these contact functions are related to the client's internal psychological functions.

Prouty (2003) defines two types of clients based on communication possibilities: "expressive" and "pre-expressive". According to him, "expressive" clients are those who are able to more easily and naturally include others in their experiences, recognizing relevant information about them [including recognizing and transmitting a sense of value to them through their attitudes]; on the other hand, patients considered as pre-expressive do not do this easily. The pre-reflexive clients seem to not be interested in being understood; it even seems they do not realize others do not understand them.

A characteristic of pre-therapy is that it does not present requirements related to the process of creating verbal meaning in the therapist/client relationship, that is, it does not require an attitude of empathic understanding by the therapist in the case of the client characterized as pre-expressive. Rather than seeking an understanding of feelings through empathic reflections, pre-therapy offers "contact reflection".

Prouty (2003) specified these "reflections" as simple procedures that can be used even by beginning therapists to develop a therapeutic relationship with totally non-communicative people. "Contact reflections" are literal manifestations of the client's verbal and non-verbal behavior and aspects of the concrete reality around them both at the present moment of the encounter, facilitating the development of the client's contact skills (Prouty, 2003).

"Contact reflections" have 5 modalities: (1) situational reflection is the process of verbally transmitting to patients what they are doing, also explaining the context in which they find themselves; (2) bodily reflection - verbal and/or bodily transmission of what they are doing to their own bodies; (3) facial expression reflex is the process of verbally transmitting the feelings they seem to be experiencing based on their facial expression; (4) word-for-word reflection is the verbal transmission through the repetition of any words or phrases that make sense in disorganized and meaningless verbalizations, even if it means repeating simple words (Karon \& VandenBos, 1981). The fifth modality (5) is reiterative reflection, consisting of repeating, in due course, and valuing some of the attempts at contact based on previous modalities that were successful in the objective of establishing psychological contact. These principles are usually sufficient

${ }^{4}$ In the original: "desenvolvimento ou o estabelecimento das funções necessárias para a relação terapêutica e a experienciação" (Prouty, 2003, p. 45). 
to transform a patient with difficulty in establishing contact into someone "responsive" within a few hours (Karon \& Vander Boss, 1981). Prouty believed that repetition in this context increases the possibility of establishing a relationship, as well as favoring the client experience process (van Werde, 2016).

Prouty (2003, p. 12, in our own translation) ${ }^{5}$ recommends to psychologists who treat psychotic patients:

Since the therapist does not experience the psychotic experience, they have to assimilate it, gradually feeling it internally. In this case, an empathetic attitude towards the loss of self-awareness and the loss of reality is needed - this is the loss of the ego itself.

He uses the concept of Einfühlung, understanding from within, as a way of being empathetic towards a psychotic experience. This concept also refers to the need for a rigorous understanding of the client's experience process, which would be the therapist's ability to understand the perception of reality that the client experiences in relation to hallucinations, trying to perceive space, colors, and other aspects as their own. A third element that this concept also seeks to cover is the therapist's need to seek to experience of what the client is experiencing in relation to the hallucination - fear, distrust, courage - that is, the therapist needs to understand the person's feelings about the hallucination, the emotions present in the psychotic space (Prouty, 2003).

Current studies point to successful applications of pre-therapy and the person-centered attitudes that support it; they can be used by different types of caregivers in different environments in which attempts of caring for and interacting with mentally disturbed people are developed. Esrkine (2015) presents benefits in a psychiatric context in a work similar to the Therapeutic Companion; Courcha (2015) focused on training home carers; Swan and Schottelkorb (2015) investigated the process of psychological change in play therapy with a child who had difficulties in establishing interpersonal contact; Štěpánková (2015) presents a phenomenological study on the experience of contact with autistic people based on empathic understanding.

There are also studies that demonstrate the effectiveness of preventive interventions against outbreaks or acute psychological crises, either through territory-based services (near the household of the person in distress) that involve the rehabilitation and recovery of distressed people in their own environment, thus avoiding hospitalizations (Davidson, 2019), either through clinical interventions that identify the triggers of acute psychotic episodes or proposing early actions that lead to the stabilization of the person before the onset (McGorry, 2020; McGorry, Trethowan, \& Rickwood, 2019; Nelson et al., 2020).

\section{Methodological foundations for a psychological intervention in psychotic crisis from the Person-Centered Approach}

What is found, in the aforementioned technical literature on the subject, are proposals for interventions that relate to a set of strategies to deal with the crisis situation based on techniques and protocols of conduct that include modes of physical restraint and psychiatric medication. What is being addressed in this article, on the other hand, refers to the complexity of fundamental elements for the development of a dialogical therapeutic relationship between the psychologist and the client in crisis.

Referring to the crisis phases delimited by Caplan (1980), this proposal is limited to the "fourth phase", where the tension rises to a breaking point, producing an important disorganization in the individual,

\footnotetext{
${ }^{5}$ In the original: "como o terapeuta não vivencia a experiência psicótica, tem que a assimilar, sentindo-a gradualmente internamente. Neste caso, é necessária uma atitude empática em relação a perda da percepção de si próprio e a perda da realidade - isto é a perda do próprio ego" 
with serious results, defining situations of "acute psychological crises" as extreme psychic experiences that include experience derealization and depersonalization, accompanied by demonstrations of despair and/or anger that, in most cases, cause psychomotor manifestations of aggressiveness towards themselves and everybody around them. These suffering experiences may be accompanied by positive symptoms, common in psychotic conditions.

Rogers (1957/1994), one of the greatest exponents of North American humanistic psychology, dedicated himself to building hypotheses about the therapist-client relationship and about the process of psychological growth, both in the context of caring for people with a relative degree of personal autonomy (Rogers, 1957/1994), and in those who need to be in custody, that is, chronic hospitalized patients (Rogers et al., 1967). Rogers, in one of the seminal works of the Person-Centered Approach, presented, based on empirical data, the proposition of six conditions/attitudes that would be necessary and sufficient for the therapeutic change of personality (Wood et al., 1994, p. 145, in our own translation) ${ }^{6}$ :

Two people are in psychological contact; 2 . The first, whom we will call the client, is in a state of incongruity, being vulnerable or anxious; 3 . The second person, whom we will call the therapist, is congruent or integrated in the relationship; 4. The therapist experiences unconditional positive regard for the client; 5 . The therapist experiences an empathic understanding of the client's internal frame of reference and endeavors to communicate this experience to the client; 6 . The communication to the client of the therapist's empathic understanding and unconditional positive regard is to a minimal degree achieved.

During the period from 1957 to 1963, Rogers et al. carried out extensive research with the Department of Psychiatry and Psychology at the University of Wisconsin (Rogers et al., 1967). This research arose from Rogers's desire to verify whether the fundamental hypotheses that shaped the therapist's attitudes in the context of Client-Centered Therapy would also be effective for people who were unwilling to receive psychological help because they considered it unnecessary or for those who, despite the severity of their clinical condition, did not realize the need for it.

In that study, Rogers found that of the three fundamental attitudes for personality development that were being put to the test - unconditional positive regard, authenticity, or congruence of the therapist and empathic understanding - those that most effectively helped in the process of developing greater personal autonomy (of people with severe personality disorder such as schizophrenic conditions) were unconditional positive regard and authenticity or congruence of the therapist; as for empathic understanding, the patient was not always able to perceive it due to the limitations imposed by the illness. In the words of Rogers et al. (1967, p. 76):

The schizophrenic individual seems to be seeking a relationship with someone they can trust, being the therapist's ability to show him or herself as a trustworthy and caring person that seems to be crucial to him. Therefore, considering our assessments, the individual's perception of the therapist's congruence and positive regard is pivotal. Only later does empathic understanding become important and perceptible to a higher degree.

Thus, at the end of that research, it was possible to conclude that the same attitudinal conditions that facilitate psychological contact and the establishment of a therapeutic relationship with neurotic people are

$\boldsymbol{\nabla} \nabla \boldsymbol{v}$

6 In the original: "1. Que duas pessoas estejam em contato psicológico; 2. Que a primeira, a quem chamaremos cliente, esteja num estado de incongruência, estando vulnerável ou ansiosa; 3. Que a segunda pessoa, a quem chamaremos de terapeuta, esteja congruente ou integrada na relação; 4. Que o terapeuta experiencie consideração positiva incondicional pelo cliente; 5. Que o terapeuta experiencie uma compreensão empática do esquema de referência interno do cliente e se esforce por comunicar esta experiência ao cliente; 6 . Que a comunicação ao cliente da compreensão empática do terapeuta e da consideração positiva incondicional seja efetivada, pelo menos num grau mínimo" (Wood et al., 1994, p. 145). 
effective in the relationship with extreme patients, as he called them (Rogers et al., 1967). In the summary of this study, Rogers et al. (1967) comment on how psychotic clients resembled other groups of clients they worked with when they realized that the former seemed to respond constructively "to subtle and liberating elements of an interpersonal relationship" (p. 93) and that, although these elements did not appear specifically in the data of the study, they were present in all data and this evidence could represent one of the most important findings of that research.

Rogers understood unconditional positive regard as a condition of the therapist's unconditional acceptance of the client as a person. "Unconditional" can be understood as an attitude that recognizes the value and dignity of clients so as not to define them based on their limitations or problems, but to recognize them as individuals with potential.

Unconditional positive regard, when communicated by the therapist, works by providing a non-threatening context in which the client can explore and experience the most deeply hidden elements of their inner selves. The therapist is not patronizing, sentimental, or superficially social and pleasant. But their deep care is a necessary ingredient to provide a "safe" context in which clients can explore themselves and share deeply with another human being (Rogers et al., 1967, p. 104).

Cury (2019) recently wrote a review of the aforementioned book, in which Rogers et al. (1967) summarized the main results of that research: (a) the most essential element for a process of personality development to occur, regardless of speaking of psychotherapy with neurotic people or those diagnosed as psychotic, or with other mental disorders, is the person-to-person relationship; (b) the elements that favor the constitution of the therapeutic relationship do not depend specifically on the therapist or the client, but rather are the result of the interaction between them; (c) psychotic patients and university students who participated in this study presented a more adequate perception about the interpersonal relationship than more experienced psychotherapists; (d) a psychological theory about the process of personality development through a therapeutic relationship can be tested in practice using suitable instruments; (e) despite the offer by the therapists of the three facilitating attitudes or conditions (acceptance, understanding, and authenticity), patients with schizophrenia had difficulty in perceiving them, but were able to develop such perception throughout the therapeutic process; (f) Patients with schizophrenia perceived the therapist's levels of acceptance, positive consideration, and authenticity more easily than empathic understanding (which neurotics seem to perceive more and more immediately); and (g) regarding the facilitating conditions made available in the context of psychiatric hospitalization, the researchers realized that the environment of a ward could significantly improve if workers made themselves available for intimate and warm conversation with the people in distress, allowing that other patients could listen in on the conversation, as the attachment of therapists to a certain standard of clinical care is neither necessary nor productive in all contexts.

For Rogers (1977), empathy is essential for establishing an effective therapeutic relationship. Based on empirical research, Rogers (1977) presented the results of an empathic relationship on people's dynamics and behavior: (a) the ideal therapist is above all an empathetic person; (b) the climate constituted by the empathic relationship is directly related to the client's self-exploration and the movement of the process; (c) empathy, when perceived by the client from the beginning of the relationship, allows the prediction of later success; (d) empathic understanding is provided by the therapist and does not depend on the client; (e) The level of empathy provided by the therapist is directly related to their clinical experience; ( $f$ ) empathy is a very special feature in a psychological relationship and psychotherapists are able to communicate it more effectively than close friends; (g) the psychotherapist's internal balance is directly related to the degree of empathy they will be able to communicate to the client; (h) the psychotherapist's lack of clinical experience may favor a low demonstration of empathy by clients; (i) the clients perceive the degree of empathy better than psychotherapists themselves; (j) intellectual brilliance and diagnostic insight are not related to empathic

8 ability; and ( $k$ ) an empathic attitude may be acquired from contact with empathetic people. 
Next, we present a vignette that aims to illustrate the concepts described above, presenting an alternative therapeutic strategy to traditional interventions for patients experiencing a psychotic crisis.

Helena was in the middle of an appointment at Unit 4, when she heard the alarm for "code red". She knew she would need to interrupt the care she was providing in order to support the team, because that day she was the psychologist on duty. She ran down the ramp towards Unit 2. As she approached the place where Gustavo was, she soon found a group of nursing technicians waiting for her. Everyone knew the institution's protocol; the agreement was to stay back to protect teammates who would initially try to intervene in the least invasive and aggressive way possible. From many meetings in which they discussed the cases as a team, using an expanded clinical understanding, the nursing technicians knew that Gustavo reacted that way, not because he was an insolent person, but because he was experiencing great suffering. Due to the fact that they were sensitized and managed to develop empathy for this type of suffering, they were able to wait patiently for the psychologist to attempt to clinically manage the situation.

Helena did not accompany Gustavo in individual consultations, but she knew a little about him from the multidisciplinary team meetings and from clinical discussions in the psychology team.

She knew he wasn't usually aggressive with other people. She knew visiting hours had just ended. She imagined that the presence of his nursing colleagues in the unit could be considered very threatening by him at that moment. Under these circumstances, she chose to ask them to wait outside and that only one of them would enter with her in a calm way and go to the nursing station, joining Carlos as she approached Gustavo.

Before entering the room, Helena had thought of going straight to talk to Gustavo, but had an intuition that she shouldn't, so as not to scare him more than he already was. She quickly thought about how best to act with Gustavo. What attitude would be best suited to calm him down and bring him back to reality? She took a moment to reflect on these questions and then decided to act in such a way as to demonstrate to Gustavo that she was not there to make any demands. He sat silently in an armchair in the TV room. Rationally, she knew the risks she was running in the face of the patient's aggressiveness; she also knew she could count on the proximity of her colleagues in case she needed them. She proceeded to the TV room...

At this point, Helena's attitude demonstrated that she favored her intuition over what would seem more reasonable from a rational point of view. She visualized some possibilities and ended up choosing to go towards something that gave her a "feeling" of good resolution. What was her goal at that time? Above all, she sought to demonstrate empathy for Gustavo's suffering.

She sat in the TV room, and there she remained, silently, for a few minutes while Gustavo walked quickly through the unit, going back and forth along the hallway. After a few more minutes, he spoke to her without, however, making eye contact:

- What are you doing here? Have you come to arrest me? Are you part of this gang?

- I'm not part of any gang, Gustavo. Carlos called us on the radio, he was worried about you and asked for more attention for you from the team.

Helena chose to objectively answer Gustavo's questioning, as truthfully as possible, while also showing consideration for him.

The other patients in the same unit stayed in their rooms or remained in the outdoor patio. The nursing team patiently followed the delicate situation so that they could help quickly, if necessary, but hoped that their intervention was not necessary, betting on the subtle and delicate intervention of their colleague.

- Gustavo, my name is Helena, you've seen me here other times. I don't want to frighten you or demand anything. But I'm worried because I'm seeing you restless and angry and it shows you're not okay; you're suffering from something very painful, but I don't know what it is. 
And she continued:

- You know Gustavo, I imagine that something serious must have happened for you to be like this. Maybe you don't want to share it with me, and I respect your decision. But I want you to know that I'm here to try to understand what's going on. Carlos told me that you had a visit from your mother and that soon after you started to get restless.

The man, with great difficulty, tries to speak, crying. He says he was being chased by the federal police. He starts to tell Helena about his delusional thoughts in which a detailed police plot appears, in which he feels guilty and very afraid of being caught by the police. He says he was being chased and was extremely distressed to be there, trapped in the hospital, because at any moment they could arrest him and take him away and that no one was understanding him. Since Carlos had told Helena that Gustavo had received his mother's visit that day, knowing that her visits were always very disturbing to her son, he had decided to stay close and noticed that the mother, upon seeing Gustavo, backed off, became more rigid and that the son, upon seeing her like this, also did not go to meet her. To Carlos's surprise, Gustavo's mother uttered the following sentence: "Oh my son, don't you love me anymore? Aren't you coming to give your mother a hug?". Gustavo, faced with this situation, was extremely restless, in an ambiguous posture. He had picked up on his mother's withdrawn reaction to seeing him and didn't approach her, respecting her retreat. But when she blamed him and called him out as an ungrateful son, Gustavo was confused, not knowing how to act. This may help understand that he probably began to feel guilty, but unable to understand what was going on. He had noticed his mother's recoil and retraction, but in a susceptive way (vague perception of an experience without conscious representation) not able to name or react to this. What had been communicated by the mother's attitudes, pointed to an affective unavailability on her part, and instead of recognizing her own difficulty, she preferred to blame the child for not getting close to her. Faced with the experience of ambiguity between what he experienced and what his mother expressed in an imperative tone, his level of anxiety and anguish increased considerably, contributing to delusional constructions that began to invade his thoughts.

It seems that such attitudes created an environment that allowed him to feel valued enough to get in touch with his own pain. At that time, Gustavo could not find ways to express and integrate it, thus falling into the field of expressions that cannot be shared socially, such as delusions and hallucinations, and that would not be understandable to other people, not for the content itself, but by the way they manifest themselves - experiences that underlie the organization of delusional and hallucinatory constructions. Gustavo, through aggressive acts, seemed to communicate extreme anguish and despair for experiencing a series of incomprehensible elements and he had not found another person who was really available to help him unravel the mysteries of his own experience. With Helena's caring presence, he could legitimate and accept his feelings and then was able to reach his pain; his tears were finally able to flow freely, and his crying showed that he was finding a satisfying way to express what he was feeling, through words rather than actions.

\section{An understanding of the psychotic crisis from the Person-Centered Approach}

Oberreiter (2018, 2020), a university professor and psychiatrist, head of the Institute of Psychotherapy at Kepler University Hospital (Linz, Austria), has developed clinical practice and research from the perspective of the Person-Centered Approach. This author refers to the compensatory character of psychotic experiences, as a creative effort by the psyche to not fully perceive loneliness, since a positive relational experience implies having a human companion that understands the person at their most intimate level.

In this way, the person in a psychotic state can be understood, above all, as a deeply lonely person, who cannot bear the awareness of having no real meaning for anyone who is significant to them, and thus 
ends up looking for the bond even if in a negative, hostile, illusory way (Oberreiter, 2018). A construction that should not be challenged, as it is just an empty appearance that works as a fragile structure that keeps one suspended so that they do not fall into the abyss of depersonalization. It is up to the professional to see the unbearable experience that causes (compensates) this construction and respond to this suffering that is rooted in the fear of depersonalization.

Rogers (1977, p. 92, in our own translation) ${ }^{7}$ has emphasized that when there is no relationship where we can communicate and be recognized in both aspects of "our divided selves - our conscious facade and our deepest level of experience - then we feel the loneliness of not being in real contact with another human being". The author stated that when empathy is "appropriate and deep, it can unlock a flow of experiences, allowing it to take its natural course" (p. 83, in our own translation) ${ }^{8}$. Elsewhere in the same text, Carl Jung is referred to as having argued that the schizophrenic would cease "to be schizophrenic when they met someone by whom they felt understood. Our practice empirically proves this statement" (Rogers 1977, p. 80 , in our own translation) ${ }^{9}$.

The perception of being understood at the deepest level of experience, in a dialogic encounter, is not a mere intervention, but a real and concrete possibility of removing the person from loneliness and anonymity. Only professionals endowed with authenticity, that is, who knows their own inner world and is aware of their own personal value, has the strength to not defend themselves - through the distance caused by the exclusive treatment of the symptom - when faced with their own depths reflected in the eyes of that person who is in a process of depersonalization.

How to authentically position oneself when facing people in a psychotic crisis? Positive symptoms such as hallucinations or delusions can express a deep desire for contact or communication that, at that moment, may be impossible and that is why this expression occurs in a peculiar way. A therapeutic presence in this context would be aimed at capturing the subjective experiences behind hallucinatory or delusional manifestations, expressed in a unique way by the person in crisis.

Oberreiter (2018) argues that the therapist must remain firm in relation to their own points of view, but if questioned by the patient, they must communicate openly and clearly, sustaining a position of respect in relation to the other person's reality. In this context, it is important for the client to realize that the psychotherapist can respect several points of view that occur simultaneously and that this can also favor a community's sense of coexistence with difference. The meaning of this attitude lies in the therapist's ability to remain authentic without actually judging the point of view of the person suffering. That open, gentle communication, permeated with unconditional positive consideration, can convey security and can be experienced as a genuine presence, which will contribute to a reduction of fantasies and mistrust.

Another important element to be considered is the therapist's confidence in the formative tendency, as it is necessary for them to be a presence that makes it easier for the person to realize that they are ingrained with resources to be able to deal with their pain. This is why tutelary and extremely welcoming attitudes can be understood as a non-recognition of the client's internal resources and favoring emotional dependence.

Therefore, it is possible to see that therapeutic care is sustained by a tension of forces that demonstrates presence and support through empathy and unconditional positive consideration, and bets on the client's ability to overcome their own difficulties through an authentic posture. Therapeutic care from this perspective

\footnotetext{
$\boldsymbol{\nabla} \nabla \mathbf{v}$
}

7 In the original: "nosso eu dividido - nossa fachada consciente e nosso nível mais profundo de experiência - então sentimos a solidão de não estarmos em contato real com nenhum outro ser humano" (Rogers 1977, p. 92).

${ }^{8}$ In the original: "adequada e profunda, pode desbloquear um fluxo de vivências, permitindo que siga seu curso natural (Rogers 1977 , p. 83).

9 In the original: "de ser esquizofrênico quando encontrasse alguém por quem se sentisse compreendido. Nossa prática comprova empiricamente essa afirmação" (Rogers 1977, p. 80). 
is a type of tension that is only possible when professionals organize themselves in the dialogical relationship through a genuine interest in being a living presence in the face of the client's needs. These are transmitted in the relationship by listening to the structure of the lived experience and not just listening to the "appearances" of the psychotic constructions. Oberreiter (2018) states that the success in building a therapeutic relationship that is valuable to the client will cause the delusional self to lose meaning and gradually dissipate.

So far, it was possible to glimpse the facilitating attitudes proposed by Rogers as the founding axis of a therapeutic relationship that favors the integration and development of the personality. There is another element present in our vignette that would be opportune to analyze more closely, since the theme proposed here is psychological intervention in a psychotic crisis. When Helena enters the TV room, she sees some possibilities and ends up choosing to go towards something that gives her a "feeling" of good resolution, thus choosing to privilege her intuition over what would seem more reasonable, from a rational point of view. From a superficial observation, this "intuitive" behavior could easily be considered as something of the order of common sense. But Helena chose to follow her own subtle impressions of the situation, something that Rogers (1986, p. 208) also refers to: "what I want is to be by their side, occasionally stepping back, sometimes stepping forward when I can see more clearly the path we are on, and stepping forward only when guided by my intuition".

Helena's intuition can be associated with the observation of her own experiential flow, a concept proposed by Eugene T. Gendlin, Carl Rogers's collaborator in research with severely ill patients (Kypriotakis, 2018). Gendlin (1964) contributed to Rogers's studies (1977) by reformulating the concept of experience, enabling him to redefine his understanding of the empathic attitude, in the last phase of his work.

For Gendlin (1964), intermittently in the human organism, there is a flow in relation to which the person can turn, using it as a reference to discover psychological meanings. The new concept of living proposed by Gendlin is called experiencing, which "is the feeling process, lived body and specifically what constitutes the basic matter of psychological and personality phenomena" (Gendlin, 1964, p. 111).

Messias and Cury (2006), in a research that related the impact of the concept of experiencing proposed by Gendlin, in the theoretical formulations and in the practice of Rogers's Person-Centered Psychotherapy, emphasize the importance of the empathic response of the therapist to the client, addressed to the subjective experience that he or she (the client) "has of a subject and not the subject itself" (p. 358, in our own translation) ${ }^{10}$. These authors explain the Felt dimension that human beings have of meanings, in a pre-conceptual field. Gendlin (2006) conceptualized the experiential flow as a felt sense (felt-sense), an experience felt bodily that, when assimilated in the novelty, reveals and allows a new meaning to emerge, even bringing with it a kind of "bodily relief", a sign that the meaning was congruent and revealed to the person the experience that they previously felt only at the bodily level.

Gendlin (2006) contributed with Rogers in the process of reformulating the concept of empathy, emphasizing a significant dimension of experience that manifests itself in the body. Gendlin (2006, p. 13, in our own translation)11 stated that we physically know about what is psychologically significant to us: "your body fully knows each of the situations in which you find yourself, knows a far greater number of aspects of these than you can imagine" and that the body is "an incredibly complex interaction with everything around it". Given these statements, it is possible to observe that Helena assumed the intention of using resonance in her own organism about the client's experience (resonance of the client's experiential flow), who could not communicate it verbally, but through other types of bodily reactions.

\footnotetext{
${ }^{10}$ In the original: "tem de um assunto e não ao assunto em si" (Messias \& Cury, 2006, p. 358).

${ }^{11}$ In the original: "Seu corpo conhece inteiramente cada uma das situações em que você se encontre, conhece uma quantidade de aspectos delas extremamente maior do que você possa imaginar" (Gendlin 2006, p. 13).
} 
She ended up accessing another dimension of knowledge, which was shown, firstly, in the form of a perception, still lacking an explicit meaning but, in delicate moments like these, it can be extremely important and necessary, since in many cases the person in distress is unable to verbalize what they feel, or their verbalization ends up being extremely distant and inconsistent with the bodily experience felt. This passage demonstrates the importance of the psychologist who intends to work in mental health contexts to know their own subjectivity well, to be able, in due course, to distance themselves from personal issues and subjectively make themselves available to welcome the experiential resonance of the person they want to help. In view of the above, it is essential that the psychologist experiences and incorporates the attitudinal conditions defined by Rogers for the development of healthy interpersonal relationships, because if they are also supported by their vanitas, they will certainly make use of several defensive resources when in contact with the person who is suffering, for not knowing how to deal with their own fears.

\section{Conclusion}

Given the elements discussed throughout this article, we sought to highlight the contribution of the Person-Centered Approach (theory and practice) to support psychological interventions of a clinical nature with patients who are facing an acute psychotic crisis in the context of institutions responsible for tertiary care in mental health. The stabilization strategy, described throughout this article, represents an alternative to the traditional forms of physical and chemical restraints, and concerns the development of a therapeutic relationship consisting of attitudes of unconditional positive regard, authenticity or congruence, and empathic understanding by the psychologist. The psychologist's availability to assume a posture guided by these attitudes, in order to understand people in distress, is essential for them to position themselves as an alterity to facilitate and help the patients to regain their mental balance.

They do this by trying to empathically understand the elements present in the immediate experience of the client in acute suffering, using in many cases subtle, susceptive impressions that can emerge from manifestations of the client's bodily dimension. The attitude of acceptance and empathic understanding in this type of intersubjective relationship is not limited to reflecting the client's feelings. It implies "learning" how that person is able to express their immediate experience, and a determination to "follow them" in their experience constituting an "active presence", able to carefully respond to the gravity of the moment. A presence that is sustained in a process of self-questioning about the necessary support (in the face of helplessness) and the necessary suspension (favoring autonomy) in a relational flow that includes a genuine concern for the other person, legitimizing their suffering in order to preserve their dignity and self-respect.

This study is based on a theoretical assumption that human acts, even the most bizarre or strange ones, are always meaningful and can be emphatically understood from their experiential dimension; however, in a situation where the person is in extreme suffering, the symbolization of the experience lived by them is secondary to another, more important perception, that they are really being considered and accepted by someone. Thus, the psychologist must be able to promote an intersubjective encounter with the person in crisis in order to communicate and have a genuine interest in helping them deal with the suffering. This is one of the most important elements in developing a relationship of psychological care with the potential to help the client leave their experience of despair, the abyss of depersonalization, and derealization.

Moreover, by appropriating these different dimensions present in clinical interventions in mental health institutions, psychologists can confirm the pertinence and importance of their participation in teams that are responsible for coping with extreme psychological suffering, seeking to reestablish personal autonomy and dignity. 


\section{Contributors}

G. W. TOSTES presented the initial data for the study and produced the narratives and theoretical dialogues. V.

E. CURY assisted in the study design, participated in the review of narratives, and in the dialogue with theories.

\section{References}

Borgna, E. (2003). Le intermitenze del cuore. Milano: Feltrinelli.

Borgna, E. (2019). Ha ancora senso la fenomenologia? Considerazioni di uno psichiatra. Encyclopaideia, 23(55), 1-4. https://doi.org/10.6092/issn.1825-8670/10082

Caplan, G. (1980). Princípios de psiquiatria preventiva. Rio de Janeiro: Zahar.

Courcha, P. (2015). "She's talking to me!" Training home carers to use Pre-Therapy contact reflections: an action research study. Person-Centered \& Experiential Psychotherapies, 14(4), 285-299. https://doi.org/10.1080/14779757.2015.1 058291

Cury, V. E. (2019). A relação terapêutica e seus impactos: um estudo da psicoterapia com esquizofrênicos. In M. Tassinari \& A. Nerys (Orgs.), Diálogos humanistas: encontros de três gerações (pp. 167-174). Curitiba: CRV. https://doi. org/10.24824/978854443180.1

Davidson, L. (2019). Recovering a Sense of self in schizophrenia. Journal of Personality, 88(1), 1-11. https://doi.org/10.1111/ jopy. 12471

Erskine, R. (2015). Meeting Vincent: reconnections from behind the wall - Pre-Therapy in a psychiatric unit contexto. Person-Centered \& Experiential Psychotherapies, 14(4), 300-309. https://doi.org/10.1080/14779757.2015.1073608

Gendlin, E. T. (1964). A theory of personality change. In P. Worchel \& D. Byrne (Eds.), Personality change (pp. 102-148). New York: John Wiley \& Sons.

Gendlin, E. T. (2006). Focalização: uma via de acesso à sabedoria corporal. São Paulo: Gaia.

Karon, B. P., \& VandenBos, G. R. (1981). Psychotherapy of schizophrenia: the treatment of choice. New York: Jason Aronson.

Kypriotakis, N. (2018). Experiencing and the person-centred approach. In M. Bazzano (Ed.). Re-Visioning Person-Centred Therapy. London: Routledge, https://doi.org/10.4324/9781351186797

McGorry, P., Trethowan, J., \& Rickwood, D. (2019). Creating headspace for integrated youth mental health care. World Psychiatry: Official Journal of the World Psychiatric Association, 18(2), 140-141. https://doi.org/10.1002/wps.20619

McGorry, P. D. (2020). Lessons learned and future directions for early intervention and youlth mental health paradigms. In P. J. Uhlhaas, J. S. Carpenter, \& I. B. Hickie (Orgs.), Youth mental health: a paradigm for prevention and early intervention. Cambridge Massachusetts: The MIT Press.

Messias, J. C. C., \& Cury, V. E. (2006). Psicoterapia centrada na pessoa e o impacto do conceito de experienciação. Psicologia: Reflexão e Crítica, 19(3), 355-361. https://doi.org/10.1590/S0102-79722006000300003

Nelson, B., Lavoie, S., Gawęda, L., Li, E., Sass, L. A., Koren, D., McGorry, P. D., Jack, B. N.; Parnas, J.; Polari, A.; Allott, K.; Hartmann, J. A.; Whitford, T. J. (2020). The neurophenomenology of early psychosis: an integrative empirical study. Consciousness and Cognition, 77(102845). https://doi.org/10.1016/j.concog.2019.102845

Oberreiter, D. (2018) The therapy of delusion in regard to vanitas, sensus communis, and para-position. Person-Centered \& Experiential Psychotherapies, 17(3), 224-240. https://doi.org/10.1080/14779757.2018.1498379

Oberreiter, D. (2020). The therapy of ego boundary disorders focusing special attention on structural empathy. Person-Centered \& Experiential Psychotherapies, 20(2), 174-194. https://doi.org/10.1080/14779757.2020.1748696

Prouty, G. (2003). Evolução teórica na terapia experiencial/centrada-na-pessoa: sua aplicação nas psicoses esquizofrênicas e de atraso mental. Lisboa: Encontro.

Reigota, M. (1999). Ecologistas. Santa Cruz do Sul: EDUNISC.

Rogers, C. R., Gendlin, E. T., Kiesler, D. J., \& Truaux, C. B. (Eds.). (1967). The therapeutic relationship and its impact: a study of psychotherapy with schizophrenics. Wisconsin: University of Wisconsin Press.

Rogers, C. R. (1994). As condições necessárias e suficientes para a mudança terapêutica de personalidade. In Wood, J. K., Doxsey, J. R., Assumpção, L. M., Tassinari, M. A., Japur, M., Serra, M. A., ... Cury, V. E. (Orgs.), Abordagem Centrada na Pessoa (pp. 155-177). Vitória: Fundação Ceciliano Abel de Almeida. (Originalmente publicado em 1957). 
Rogers, C. R. (1986). Client-centered therapy. In I. L. Kutash \& A. Wolf (Eds.), Psychotherapist's casebook (pp. 197-208). Jossey-Bass Publishers.

Rogers, C. R. (1977). Uma maneira negligenciada de ser: a maneira empática. In C. R. Rogers \& R. L. Rosenberg (Orgs.), A pessoa como centro (pp. 69-89). São Paulo: EPU.

Rojo, V. I., \& Peral, D. D. (2009). Comunicación con personas en crisis psicóticas. In E. P. Torres (Coord.), Psicologia y emergencia: habilidades psicologicas en las profesiones de socorro y emergencia (pp. 457- 482). Bilbao: Desclée De Brouwer.

Slaikeu, K. (1988). Intervención en crisis: manual para practica e investigación. Ciudad de México: El Manual Moderno.

Štěpánková, R. (2015). The experience with a person with autism. Phenomenological study of the experience with contact and contact reflections. Person-Centered \& Experiential Psychotherapies, 14(4), 310-327. https://doi.org/10.1080/1 4779757.2015.1038396

Swan, K. L., \& Schottelkorb, A. A. (2015). Contact work in child-centered play therapy: a case study. Person-Centered \& Experiential Psychotherapies, 14(4), 268-284. https://doi.org/10.1080/14779757.2014.976798

van Werde, D. (2016). Pre-Therapy and working on contact. In C. Lago \& D. Charura (Eds.), Person-centred Counselling and psychotherapy handbook: origins, developments and current applications (pp. 179-187). England: McGraw-Hill Education, Open University Press.

Wood, J. K., Assumpção, M. L., Tassinari, M. A., Japur, M., Serra, M., \& Rosenthal, R. W. (Orgs.) (1994). Abordagem centrada na pessoa. Vitória: Fundação Ceciliano Abel de Almeida.

Received: May 21, 2020

Final version: May 25, 2021

Approved: August 5, 2021 